\title{
KARO'S LOCAL WISDOM: THE USE OF WOODY PLANTS FOR TRADITIONAL DIABETIC MEDICINES
}

\author{
Rospita O.P. Situmorang*, Alfonsus H. Harianja and Johansen Silalahi \\ Aek Nauli Forestry Research Institute, Jl. Parapat KM. 10 Sibaganding Village, Parapat City, \\ North Sumatra, Indonesia
}

Received: 13 August 2014, Revised: 9 July 2015, Accepted: 6 September 2015

KARO'S LOCAL WISDOM: THE USE OF WOODY PLANTS FOR TRADITIONAL DIABETIC MEDICINES. This paper identifies the plant species used traditionally by Karo people in North Sumatra, to cure diabetes, analyses the cultural significance index of those plants for the Karo, and clarifies phytochemical contents of the plants. Data were collected using survey method from selected respondents $(\mathrm{n}=54)$ based on their knowledge and practices in utilising medicinal plants to cure diabetic disease. Index of Cultural Significance (ICS) of plants was determined using the method proposed by Turner. Results showed that twelve woody plant species have been used to cure diabetes: loning leave (Psychotria sp.), kacihe leave (Prunus accuminta Hook), umbrella tree leave (Maesopsis eminii Engl), mutamba leave (Guazuma ulmifolia Lamk), cepcepan leave (Villebrunea subescens Blume), pirdot/cepcepan lembu leave (Saurauia vulcani Korth), raru bark (Cotylelobium melanoxylo), breadfruit leave (Artocarpus altilis), salam leave (Sysygium polyanthum Wight), mahogany seed (Swietenia mahagoni (L.) Jacq), cinnamon bark (Cinnamomum burmani), and yellow bamboo rod (Bambusa vulgaris Schrad). Five of those plants: loning, umbrella tree, mutamba, raru and salam have the highest cultural significance level. These five plants are highly needed in large quatities by the Karo people, so their availability in the forest should be securely conserved and protected. The plants used contained alkaloids, flavonoids, phenolics and terpenoids which can help to lower blood sugar level.

Keywords: Ethnobotany, Karo ethnic, diabetic medicines, Index of Cultural Significance (ICS), phytochemical

KEARIFAN LOKAL MASYARAKAT KARO: PENGGUNAAN TANAMAN BERKAYU UNTUK OBAT TRADISONALPENYAKIT DLABETES. Tulisan ini mengidentifikasi jenis-jenis tanaman yang digunakan oleh masyarakat Karo secara tradisional di Sumatara Utara, Indonesia, untuk. mengobati diabetes. Jenis-jenis tanaman tersebut dianalisis indeks kepentingan budayanya (ICS) dan diklarifikasi kandungan fitokimianya. Metode survey digunakan dengan responden terpilib (n-54) berdasarkan pengetabuan mereka dalam memanfaatkan obat-obat tradisional untuk diabetes. Indeks kepentingan budaya (ICS) dari masing-masing tanaman diukur menggunakan metode yang dipakai oleh Turner. Hasil penelitian menunjukkan terdapat 12 jenis tanaman berkayu untuk mengobati diabetes: loning (Psychotria sp.), kacihe (Prunus accuminta Hook), kayu afrika (Maesopsis eminii Engl), jati belanda (Guazuma ulmifolia Lamk), cepcepan (Villebrunea subescens Blume), pirdot/cepcepan lembu (Saurauia vulcani Korth), raru (Cotylelobium melanoxylo), sukun (Artocarpus altilis), salam (Syzygium polyanthum Wight), mahoni (Swietenia mahagoni (L.) Jacq), kulit manis (Cinnamomum burmanni), dan bambu kuning (Bambusa vulgaris Schrad). Lima jenis tanaman: loning, kayu afrika, jati belanda, raru dan salam memiliki tingkat kepetingan budaya tertinggi yang dibutubkan dalam jumlah yang banyak dibandingkan tanaman lain sehingga ketersediaannya di butan harus dikonservasi dan dilindungi. Tanaman-tanaman yang dipakai oleh masyarakat tersebut mengandung alkaloid, flavonoid, fenolik dan terpenoid yang mampu menurunkan kadar gula darah.

Kata kunci: Etnobotani, Masyarakat Karo, obat diabetes, indeks kepentingan budaya (ICS), fitokimia

*Corresponding author: pita_80s@yahoo.com 


\section{INTRODUCTION}

Traditional communities have high dependency on a variety of plants as a source of food, medicine and for traditional ceremonial purposes (Winarti \& Nurdjanah, 2005; Gerique, 2006; Das, Gupta, Nath, \& Mustapha, 2013). Local knowledge of existing vegetation is developed based on experiences that has been tested for centuries and adapted to the local culture and environment (Martin, 1995; Waluyo, 2008; Hasibuan, 2011). This knowledge is known as local wisdom. Local wisdom is a basic knowledge gained from living in balance with nature. It is related to culture in the community which is accumulated and passed on from generation to generation. This wisdom can be both abstract and concrete, but the important characteristics come from experiences or evidences gained from life. The wisdom from real experiences integrates the body, the spirit and the environment (Mungmachon, 2012).

Karo people are spread in many regions of North Sumatra Province, Indonesia, but their origin are from the Karo Regency. They migrated to various places such as Medan City, Binjai, Deli Serdang, Langkat, and Simalungun Regency. The size of Karo regency is $2.97 \%$ of the North Sumatra Province. Karonese population in North Sumatra in 2011 was about 913.000 people or $6.90 \%$ of the total population of North Sumatra (North Sumatra Statistical Bureau, 2012; Karo Regency Statistical Bureau, 2012).

Karo people use various plant species for their daily life including for medicines. In terms of illness treatment, they have a philosophy "lit bisa lit tawar" which means that all diseases can be treated or cured. They strongly believe that the nature provides medicines to cure diseases. The use of natural resources as medicines for curing diseases including diabetes practiced by Karo as part of their culture since long time ago.

Widowati, Dzulkarnain, and Sa'roni (1997) stated that diabetes mellitus is a carbohydrate metabolism disorder characterised by high blood sugar level (hyperglycaemia) and the presence of glucose in urine (glucosuria).
Complications of the disease can increase the risk of heart attack and stroke. This disease is also closely associated with the blood circulation if left untreated, diabetes can cause many complications like kidney's damage, eye problems, nerve cell damages, depressions, slow healing of skin diseases, gum and urinary tract infections (Widowati et al., 1997; Alexious \& Demopoulos, 2010). Ministry of Health of Republic Indonesia (2012) stated that diabetes is the sixth fatal disease in Indonesia. Due to the seriousness of this disease, people with diabetes usually take many types of treatment including traditional medicine.

Ethnobotany research is conducted to explore the cultural heritage as well as elaborating the potential of existing plants in the forest and environment (Windadri, Rahayu, \& Uji, \& Rustiami, 2006; Waluyo, 2008). The study primarily aimed to discover chemical compounds which are useful in the manufacturing of modern medicines to cure dangerous diseases such as cancer, AIDS, and others. Many researchers, especially those from Europe, have been conducting ethnobotany researches to obtain new chemical material for modern medicine. In the last decade, they began to shift ethnobotany research to Asia. Indonesia is preferred by the ethnobotany researchers as one of the research sites because its biodiversity richness is the second largest to Brazil (Ministry of Forestry of Republic Indonesia, 2010).

Raw materials of traditional medicines are generally supplied from the forests. Harianja (2012) stated that traditional medicine entrepreneurs in Karo Regency still utilise the natural forest to obtain the raw materials for the medicine. Forest area in Karo Regency is about $125,536.50$ ha and $78.58 \%$ of the total forest area and it is a protected forest (Karo Regency Statistical Bureau, 2012). The forest area is dominated by local and exotic woody plants, such as Pinus merkusii, Altingia exelsa, Schima wallichii, Podocarpus sp., Toona sureni, local fruit plants such as durian (Durio zibethinus), dadap (Erytbrima subumbrans), rambutan (Niphelliun lappacium), pulai (Alstonia scholaris), palm sugar (Arenga pinnata), and rattan (Calamus caesius) 


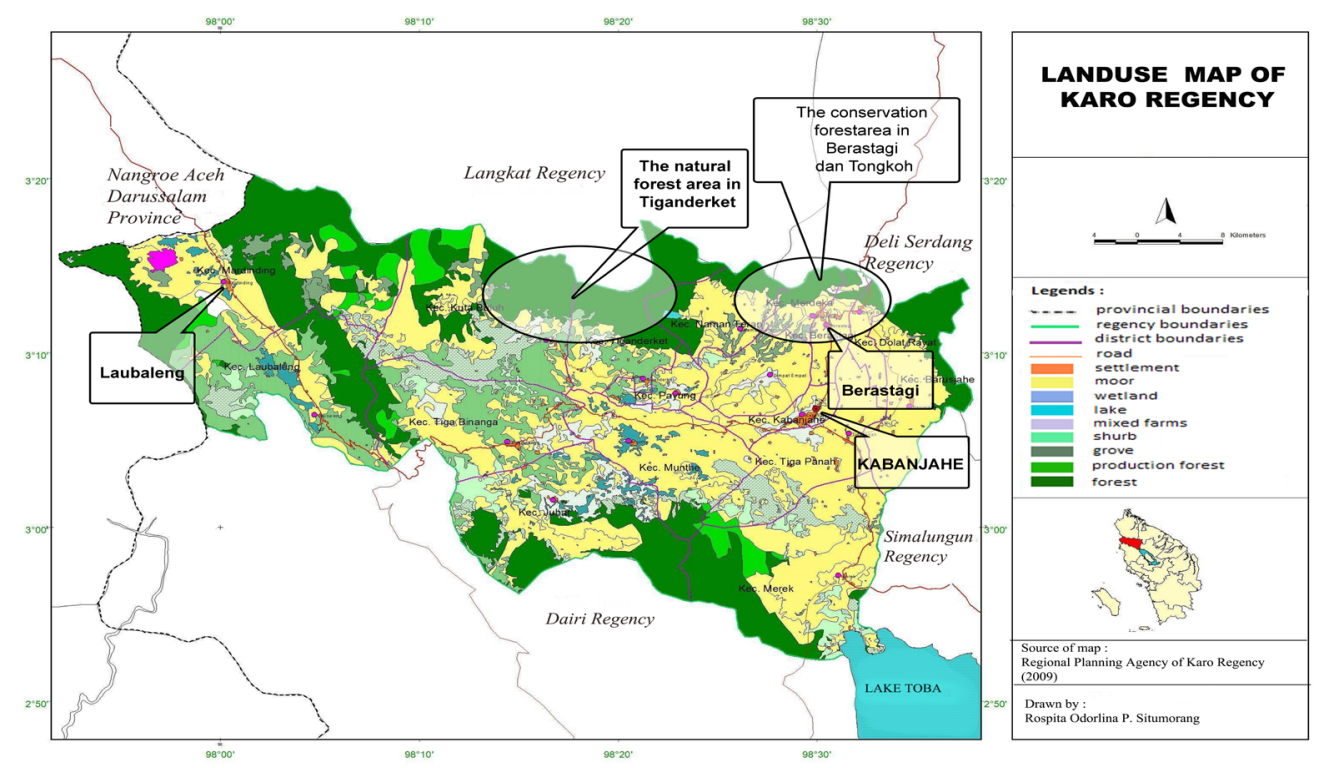

Figure 1. Research location in Karo Regency, North Sumatra, Indonesia

(Forestry Planning Agency, 2002).

Ethnobotanical research of medicinal plants is also important for conserving forests, endangered plant species, and cultural heritages; increasing the potential economic value of useful plants, and introducing natural drugs. Karo community is used to consume traditional medicines (Harianja, 2012), so they know the potential of various raw materials for ethnobotany study. Research on utilisation of plants for medicines has been done by many researchers (Bailey \& Day, 1998; Batubara, Darusman, Mitsunaga, Rahminiwati, \& Djauhari, 2010), but research on woody plants for treatment of diabetes is still limited. This paper aims to identify the woody plant species, parts of the plants used and processed by the Karo people for diabetes treatment, to assess the cultural significance value of those woody plants, and to analyse their phytochemical contents.

\section{MATERIAL AND METHOD}

\section{A. Location and Time}

The research was conducted in Karo Regency, North Sumatra Province, Indonesia, that is geographically located between 2050' - 3019’ North and 97055' - 98038' East
(Karo Regency Statistical Bureau, 2012). Survey on utilisation of various woody plants for traditional medicine was conducted at Kabanjahe ( $3^{\circ} 5^{\prime} 52.70^{\prime \prime} \mathrm{N}$ and $98^{\circ} 29^{\prime} 30.78^{\prime \prime} \mathrm{E}$ ), Berastagi $\left(3^{\circ} 11^{\prime} 24.68^{\prime \prime} \mathrm{N}\right.$ and $\left.98^{\circ} 30^{\prime} 34.94^{\prime \prime} \mathrm{E}\right)$, Tongkoh $\left(3^{\circ} 12^{\prime} 28.72^{\prime \prime N}\right.$ and $\left.98^{\circ} 32^{\prime} 15.41^{\prime \prime E}\right)$, Katepul ( $\left.3^{\circ} 5^{\prime} 55.64^{\prime \prime} \mathrm{N}, 98^{\circ} 30^{\prime} 16.09^{\prime \prime} \mathrm{E}\right)$, and Laubaleng Villages $\left(3^{\circ} 11^{\prime} 9.62^{\prime \prime} \mathrm{N}\right.$ and $98^{\circ}$ 2'34.01"E). Sample plants were collected from conservation forest in Tiganderket $\left(3^{\circ} 10^{\prime} 56.35^{\prime \prime} \mathrm{N}\right.$ and $\left.98^{\circ} 19^{\prime} 39.13^{\prime \prime} \mathrm{E}\right)$, Berastagi and Tongkoh Villages (03001'10"-03019'37' N and 98012'16"-98041'00" E). The research was undertaken from April to November 2013.

\section{B. Data Collection and Sampling Techniques}

Primary data were gathered through observations and surveys. Respondents and informants were selected purposively comprising of 48 respondents of patients, farmers, local merchants, processors, and collectors, and 6 government officials as key informants. Sample trees used by the respondents to cure diabetes were collected from the conservation forest for identifying their scientific names according to a systematic plant classification in the Conservation and Rehabilitation Research and 
Development Centre in Bogor. Parts of plants identified were leaves, flowers, barks, and fruits.

\section{Determination of Index of Cultural Significance}

Data of plants, parts of plant, processing methods and the application in diabetes treatment are presented in Table 1 tables and then analysed descriptively. While the level of respondents' preference in utilising this natural medicine is analysed by using the Index of Cultural Significance (ICS) with the following formula:

$$
\begin{aligned}
\mathrm{ICS} & =\sum_{i=1}^{n} \text { (q. i. e)n } \\
\mathrm{ICS} & =\text { Total utilisation of a plant }(1, \ldots, \mathrm{n}) \\
\mathrm{n} & =\text { utility values } \\
\mathrm{q} & =\text { quality values } \\
\mathrm{i} & =\text { intensity values } \\
\mathrm{e} & =\text { exclusivity values }
\end{aligned}
$$

The value of quality, intensity and exclusivity are scored using the scoring method proposed by Turner (1988) as cited by Sari (2009) as described below:

Quality value is estimated by scoring the value of plant species, which are: $5=$ staple; $4=$ secondary material/extra + primary material; 3 $=$ other materials + secondary + medicinal plant material; 2 = ritual, mythology, recreation and so forth; 1 = unknown significance. Intensity value describes the intensity of utilisation of plant species, which are: $5=$ very high intensity; $4=$ high intensity $; 3=$ moderate intensity; $2=$ low (minimum), and 1 = very rarely use;

Exclusivity value describes the preference levels, which are: $2=$ most preferred (the ultimate choice) and unchangeable; $1=$ there are several substitutions to the original plants; and $0,5=$ secondary source.

\section{Phytochemical screening}

Phytochemical screening is a qualitative analysis of the secondary metabolite compounds (Harborne, 1987). Bioactive substances tested usually contain tannins, alkaloids, carbohydrates, terpenoids, steroids and flavonoids. These compounds are synthesised by primary or rather secondary metabolism of living (Mann, 1987;
Edoga, Okwu, \& Mbaebie, 2005). The testing performed in this study was preliminary for testing the presence of the different chemical groups (Rajani \& Kanaki, 2008).

Literature reviews of previous studies were used first to find out the chemical compounds of several medicinal plants used by Karo people and other plants and were tested using phytochemical screening method in the laboratory. This research conducted only a preliminary test of the chemical compounds. To find out more of the pharmacologically compounds, further testing is still required. Four samples were tested in the laboratory i.e. pirdot leaves, loning leaves, yellow bamboo, and umbrella tree leaves. The secondary metabolite compounds tested were alkaloids, steroids, flavonoids, tannins, terpenoids and saponins. The phytochemical analysis was conducted at the Phytochemistry Laboratory, Faculty of Pharmacy, North Sumatra University.

\section{RESULT AND DISCUSSION}

\section{A. The species of woody plants used for diabetes treatment by the Karo.}

There are 12 woody plant species from 11 families used by the Karo people in the treatment of diabetes. Most of the plants are dicotyledonous plants except bamboo which is monocotyledonous. Table 1 shows the scientific and local names of the plants, part of the plants used for diabetes treatment, and method of medicine preparation and suggested dosage/ consumption.

The plant samples were collected from the Karo forest areas at an altitude of about 850 1400 meters above sea level except raru barks which were taken from outside of Karo area. Raru (Cotylelobium melanoxylon Pierre and Shorea balanocarpoides) according to Pasaribu (2009), are grown in the Central Tapanuli and Simalungun Regency forests at an altitude of 100-800 meters above sea level.

Karo people commonly process medical plants into medical concoctions with a very simple technique through boiling the plant 
Table 1 . The woody plant species utilised by the Karo people to cure diabetes

\begin{tabular}{|c|c|c|c|c|}
\hline No. & Scientific name/Family & Local name & Part used & Material preparation and dosage/consumption \\
\hline 1. & Psychotria sp./ Rubiaceae & Loning & Leaf & $\begin{array}{l}\text { A handful of dried leaves are mixed with } 2 \text { liter of } \\
\text { water and then boiled until the water is reduced to } \\
\text { about one third of its original volume. The remaining } \\
\text { water/liquid is consumed twice a day. }\end{array}$ \\
\hline 2. & $\begin{array}{l}\text { Prunus acuminta Hook/ } \\
\text { Rosaceae }\end{array}$ & Kacihe & Leaf & $\begin{array}{l}9-10 \text { pieces of dried leaves are boiled in } 1 \text { liter water } \\
\text { until approximately } 1 / 2 \text { part of water is remaining, } \\
\text { and then consumed twice a day. }\end{array}$ \\
\hline 3. & $\begin{array}{l}\text { Maesopsis eminii Engl/ } \\
\text { Rhamnaceae }\end{array}$ & $\begin{array}{l}\text { Umbrella tree/ Kayu } \\
\text { Afrika }\end{array}$ & Leaf & $\begin{array}{l}\text { Fresh leaves or dried leaves ( } 5-8 \text { pieces) are boiled } \\
\text { in } 1 \text { liter water until } 2 / 3 \text { part is remaining and then } \\
\text { consumed twice up to three times a day. }\end{array}$ \\
\hline 4. & $\begin{array}{l}\text { Guazuma ulmifolia Lamk/ } \\
\text { Sterculiaceae }\end{array}$ & $\begin{array}{l}\text { Mutamba/ Jati } \\
\text { belanda }\end{array}$ & Leaf & $\begin{array}{l}\text { A handful of dried leaves are boiled in } 2 \text { liter of wa- } \\
\text { ter until } 1 / 3 \text { part is remaining and then consumed } \\
\text { twice a day. }\end{array}$ \\
\hline 5. & $\begin{array}{l}\text { Bambusa vulgaris Schrad/ } \\
\text { Gramnineae }\end{array}$ & Yellow bamboo & Rod & $\begin{array}{l}10-12 \text { pieces of a } 1 \mathrm{~cm} \text { cubes from the rod are boiled } \\
\text { in } 2 \text { liters of palm sap until } 1 / 2 \text { part is remaining and } \\
\text { then consumed twice a day. }\end{array}$ \\
\hline 6. & $\begin{array}{l}\text { Saurania vulcani Korth/ } \\
\text { Actinidiaceae }\end{array}$ & $\begin{array}{l}\text { Pirdot, Cepcepan } \\
\text { lembu }\end{array}$ & Leaf & $\begin{array}{l}\text { Dried leaves ( } 5-8 \text { pieces) are boiled in } 1 \text { liter of water } \\
\text { until half part is remaining and then consumed twice } \\
\text { up to three times a day. }\end{array}$ \\
\hline 7. & $\begin{array}{l}\text { Cotylelobium melanoxylon } \\
\text { Pierre/ Dipterocarpaceae }\end{array}$ & Raru & Bark & $\begin{array}{l}\text { The bark of } 3-4 \mathrm{~cm} \text { long and } 1-2 \mathrm{~cm} \text { width is cut into } \\
\text { smaller sizes. Then they are boiled in } 2 \text { liters of water } \\
\text { until half part is remaining and consumed twice a } \\
\text { day }\end{array}$ \\
\hline 8. & $\begin{array}{l}\text { Shorea balanocarpoides } \\
\text { Symington/ } \\
\text { Dipterocarpaceae }\end{array}$ & Raru & Bark & $\begin{array}{l}\text { The bark of } 3-4 \mathrm{~cm} \text { long and } 1-2 \mathrm{~cm} \text { width is cut } \\
\text { into smaller sizes. Then they are boiled in } 2 \text { liters of } \\
\text { water until half of it is remaining. Then it is drunk } \\
\text { twice a day. }\end{array}$ \\
\hline 9. & $\begin{array}{l}\text { Artocarpus altilis/ } \\
\text { Moraceae }\end{array}$ & Breadfruit & Leaf & $\begin{array}{l}\text { The chopped dried leaves, approximately a half } \\
\text { handheld quantity are taken and boiled in } 2 \text { liters of } \\
\text { water until } 1 / 3 \text { part of the water is remaining and } \\
\text { consumed twice a day. }\end{array}$ \\
\hline 10. & $\begin{array}{l}\text { Sysygium polyanthum } \\
\text { Wight/ Myrtaceae }\end{array}$ & Salam & Leaf & $\begin{array}{l}\text { - 5-8 pieces dried leaves boiled in } 2 \text { liter of water } \\
\text { until about } 1 / 2 \text { part of extract left and it is con- } \\
\text { sumed } 2-3 \text { times a day. } \\
\text { A handful dried leaves mixed with dried cinna- } \\
\text { mon bark, the size of a finger pinkie. Materials } \\
\text { are meshed to flour. A spoonful (approximately } \\
1 \text { gram) is brewed in a cup boiled water, then it } \\
\text { is consumed } 1-2 \text { times a day. }\end{array}$ \\
\hline 11. & $\begin{array}{l}\text { Swietenia mahagoni (L.) } \\
\text { Jacq/ Meliaceae }\end{array}$ & Mahogany & Seed & $\begin{array}{l}\text { Mahogany seeds are crushed to a finer size. A spoon- } \\
\text { ful of mahogany fraction is boiled in } 2 \text { liters of water } \\
\text { until } 3 / 4 \text { of it is remaining. The extract is consumed } \\
\text { once up to twice a day. }\end{array}$ \\
\hline 12. & $\begin{array}{l}\text { Cinnamomum burmannil } \\
\text { Lauraceae }\end{array}$ & Cinnamon & Bark & $\begin{array}{l}\text { Bark size of } 3 \text { to } 4 \mathrm{~cm} \text { is boiled in } 1 \text { liter water until } \\
\text { half of it is remaining, and then the extract is con- } \\
\text { sumed } 1-2 \text { times a day. }\end{array}$ \\
\hline
\end{tabular}


parts at a certain dose and then drinking the remaining water. They believe that boiling is a simple way to separate the useful substances from the plants. Boiling aims to extract medicinal compounds that dissolve in the water (polar). Thus extraction using the boiling method can separate the chemical constituents from the plant tissue. Heating process can accelerate the extraction process because high temperature will soften plant tissue so that extraction becomes faster. The second method is flouring plant parts that are listed in Table 1 with other materials such as betel leaves, various palm (riman and pinang) roots, turmeric, ginger and lime. Karo people believe that this process can enrich and thus strengthen the efficacy of the medicinal plants.

Karo people gather medical plants from nearby forests, fields, home gardens or purchasing it from local vendors. The forests are spread over Mount Sinabung, Simpang Empat, Namanteran, Tiganderket, Payung, Laubaleng and Mardingding Districts, Bukit Barisan Mountain, Merek, and Forest Conservation Park in the Districts of Berastagi and Dolatrayat. The knowledge of traditional medicine among Karo people has been passed from generations to generations. These traditional medicines are widely known as "Karo medicines" which are easily found at traditional markets in Karo Regency and neighboring areas. The raw materials for the medicines such as leaves, stems, roots and dried fruits are also available at the traditional markets in Kabanjahe and other markets in Berastagi and Tigapanah.

\section{B. The Level of Cultural Significance}

The level of cultural significance of various woody plants used for the treatment of diabetes is listed based on intensity and exclusiveness of its utilisation. The value of cultural significance (ICS) of each plant is presented in Table 2.

Table 2 shows five highest ICS values are belonging to loning tree, umbrella tree, mutamba, raru and salam. Result show that these plants are the most preferred and utilised intensively by the Karo people for diabetic treatment that might will affect those plants' existence in the forest. In order to avoid the extinction of these medicinal plants in their habitats, they should be cultivated either in-situ or ex-situ. Cultivation techniques (silviculture) should be taught and disseminated to farmers. Some of those species such as raru (Cotylelobium melanoxylon) is listed as endangered species (IUCN, 2014) and mahogany (Swietenia mahagoni (L.) Jacq) is listed in APPENDIX II (CITES, 2012; lists species that are not necessarily now threatened with extinction but that may become so unless trade is closely controlled).

\section{Chemical Compounds}

Medical and pharmaceuticals technology in the world rely on the introduction of modern treatment and isolation of various chemical elements contained in the plant materials. One of the tests used to determine the chemical contents of a plant's material is through phytochemical screening which is described as a way to determine the qualitative content of the secondary metabolites of natural materials (Pasaribu, 2009).

Information of phytochemical contents of some woody plants that also are used by Karo people as diabetic medicines is gathered from literatures as presented in Table 3. Other woody plants tested in the laboratory with their results are presented in Table 4.

Tables 3 and 4 showed that alkaloids, flavonoids, phenolic (tannins) and terpenoids are present in pirdot leave, mutamba leave, cinnamon bark, loning leave, umbrella tree leave, salam leave, raru bark, breadfruit leave, and mahogany seed. While phytochemical screening of kacihe leaves (Prunus acuminta Hook) was not done in this study due to the very low level of usage of this species by the Karo community. This plant is less desirable in treatment of diabetes because it is considered less potent than other types so it had not been used lately.

According to previous research, those active compounds have hypoglycemic activity that decreases blood sugar level (Lumbanraja, 
Tabel 2. Index of Cultural Significance (ICS) of diabetic medicinal plants

\begin{tabular}{|c|c|c|c|c|}
\hline No. & Family name & Scientific name & Local name & ICS value \\
\hline 1. & Rubiaceae & Psychotria sp. & Loning (Karo) & 170 \\
\hline 2. & Rhamnaceae & Maesopsis eminii Engl & Kayu afrika & 125 \\
\hline 3. & Sterculiaceae & Guazuma ulmifolia Lamk & Mutamba/ Jati belanda & 103 \\
\hline 4. & Dipterocarpaceae & Cotylelobium melanoxylon Pierre & Raru (Batak, Karo) & 93 \\
\hline 5. & Dipterocarpaceae & $\begin{array}{l}\text { Shorea balanocarpoides } \\
\text { Symington }\end{array}$ & Raru (Batak, Karo) & 93 \\
\hline 6. & Myrtaceae & Sysygium polyanthum Wight & Salam & 83 \\
\hline 7. & Actinidiaceae & & $\begin{array}{l}\text { Cepcepan lembu } \\
\text { (Karo), Pirdot (Batak) }\end{array}$ & 49 \\
\hline 8. & Meliaceae & Swietenia mabagoni (L.) Jacq & Mahogany & 48 \\
\hline 9. & Moraceae & $\begin{array}{l}\text { Artocarpus altilis } \\
\text { (Park.) Fosberg }\end{array}$ & Breadfruit & 41 \\
\hline 10. & Lauraceae & Cinnamomum burmanii & Cinnamon & 28 \\
\hline 11. & Gramnineae & Bambusa vulgaris Schrad. & Yellow bamboo & 25 \\
\hline 12. & Rosaceae & Prunus acuminata Hook & Kacihe (Karo) & 13 \\
\hline
\end{tabular}

Remark: $\mathrm{n}=48$

2008; Pasaribu, 2009; Ngadiwiyana et al, 2011). Table 3 shows that mahogany seeds contain saponins, flavonoids and alkaloids. Lumbanraja (2008) stated that mahogany seeds extracted with ethanol would lower blood sugar levels. Raru wood extract contains flavonoids, tannins and saponins which are also lowering blood sugar levels through inhibition of the activity of $\alpha$-glucosidace enzyme. This enzyme breaks polysaccharides into simple molecules that can be absorbed by the blood (Pasaribu, 2009). The most responsible chemical compounds for curing diabetes is belong to phenolic groups, namely cinnamaldehyde. Ngadiwiyana et al., 2011 stated that cinnamaldehyde isolated from cinnamon bark can inhibit the action of $\alpha$-glucosidace enzyme, so it has the potential to decrease blood sugar level.
Based on above results, it can be concluded that indigenous knowledge of Karo people in identifying and utilising woody plants for traditional diabetic drugs is not contradicting to pharmacology. The varieties of the plants used by Karo people generally contain the active compounds that are studied in most researches (Table 3 and 4). A research conducted by Giri (2008) on the potency of salam leaf (Syzygium polyanthum Wight) to reduce the blood sugar level, concluded that the blood sugar level in the treated mice inducted with hyperglicea had significant effect on the decrease of the blood sugar level. However, to determine the most active compound that acts to degrade blood sugar level needs further tests on various types of pharmaceuticals that were not yet conducted in this study. The tests that should be done 
Table 3. Phytochemical content of woody plants used by Karo people as diabetes medicine based on literature review

\begin{tabular}{|c|c|c|c|c|c|c|c|c|c|}
\hline \multirow[b]{2}{*}{ No. } & \multirow[b]{2}{*}{ Name/ part used } & \multicolumn{7}{|c|}{ Chemical compounds } & \multirow[b]{2}{*}{ Literatures Source } \\
\hline & & $\frac{0}{\frac{0}{0}}$ & $\begin{array}{l}\frac{\infty}{0} \\
.0 \\
\stackrel{0}{0} \\
\stackrel{4}{\infty}\end{array}$ & $\begin{array}{l}\frac{n}{0} \\
.0 \\
0 \\
0 \\
0 \\
\frac{\pi}{I}\end{array}$ & $\underset{\underbrace{}}{\stackrel{\Xi}{G}}$ & 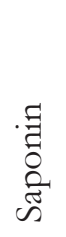 & 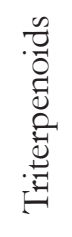 & 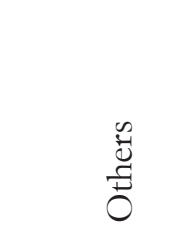 & \\
\hline 1. & $\begin{array}{l}\text { Swietenia mahagoni } \\
\text { (L.) Jacq seed }\end{array}$ & + & - & + & - & + & - & - & $\begin{array}{l}\text { Hariana, 2007; } \\
\text { Lumbanraja, } 2008 .\end{array}$ \\
\hline 2. & $\begin{array}{l}\text { Artocarpus altilis } \\
\text { (Park.) Fosberg / } \\
\text { leaf }\end{array}$ & - & - & + & + & + & - & $\begin{array}{l}\text { hydrocyanic } \\
\text { acid, acetyl } \\
\text { choline }\end{array}$ & $\begin{array}{l}\text { Ministry of Health of } \\
\text { Republic Indonesia, } \\
1997\end{array}$ \\
\hline 3. & $\begin{array}{l}\text { Cotylelobium } \\
\text { melanoxylon Pierre } \\
\text { /bark }\end{array}$ & - & - & + & + & + & + & - & Pasaribu, 2009 \\
\hline 4. & $\begin{array}{l}\text { Shorea } \\
\text { balanocarpoides } \\
\text { Symington / bark }\end{array}$ & - & - & + & + & + & - & - & Pasaribu, 2009 \\
\hline 5. & $\begin{array}{l}\text { Cinnamomum } \\
\text { burmanï / bark }\end{array}$ & + & - & + & + & + & + & - & Sufriadi, 2006 \\
\hline 6. & $\begin{array}{l}\text { Guazuma ulmifolia } \\
\text { Lamk/Leaf }\end{array}$ & + & + & + & + & + & + & - & $\begin{array}{l}\text { Dzulkarnaen \& } \\
\text { Widowati, 1996; Umar, } \\
2008\end{array}$ \\
\hline 7. & $\begin{array}{l}\text { Syzygium polyanthum } \\
\text { Wight / leaf }\end{array}$ & - & - & + & + & + & - & - & $\begin{array}{l}\text { Sulistiyani et al., 2010; } \\
\text { Oktavia, } 2011\end{array}$ \\
\hline
\end{tabular}

should include isolation of active compounds and test on extracts or isolates in experimental animals.

\section{CONCLUSION}

The Karo people in North Sumatra possess local knowledge that has been transferred from generations to generations for using parts of 12 woody plants as diabetic medicines, i.e. loning leave (Psychotria sp.), kacihe leave (Prunus accuminata Hook), umbrella tree leave (Maesopsis eminii Engl), mutamba leave (Guaruma ulmifolia Lamk), cepcepan leave (Villebrunea subescens Blume), pirdot/cepcepan lembu leave (Saurania vulcani Korth), raru bark (Cotylelobium melanoxylon), breadfruit leave (Artocarpus altilis), salam leave (Sysygium polyanthum Wight), mahogany seed (Swietenia mahagoni (L.) Jacq), cinnamon bark (Cinnamomum burmanni), and yellow bamboo rod (Bambusa vulgaris Schrad). Five plants have proved to be the most preferred and utilised intensively by the Karo people for diabetic treatment, i.e. loning tree, umbrella tree, mutamba, raru and salam, so they need to be conserved through in-situ or ex-situ techniques to avoid extinction.

Chemical compounds in those 12 woody plants have proven to decrease blood sugar level. It means that the traditional knowledge of Karo people in utilising woody plants as diabetic medicine complies with pharmacology, however further research is still needed on 
Table 4. The phytochemical contents of several woody medicinal plants tested in laboratory

\begin{tabular}{|c|c|c|c|c|c|c|c|c|}
\hline \multirow[b]{2}{*}{ No. } & \multirow{2}{*}{$\begin{array}{l}\text { Samples of } \\
\text { plants }\end{array}$} & \multicolumn{3}{|c|}{ Alkaloids } & \multirow[b]{2}{*}{ Steroids } & \multirow[b]{2}{*}{ Tannins } & \multicolumn{2}{|c|}{ Flavonoids } \\
\hline & & Meyer & Dragendrof & Bouchardar & & & $\begin{array}{c}\mathrm{Zn} \\
\text { reagent }\end{array}$ & $\begin{array}{c}\text { Mg } \\
\text { reagent }\end{array}$ \\
\hline 1. & Pirdot leaves & + & + & + & + & + & + & + \\
\hline 2. & Loning leaves & + & + & + & + & - & + & + \\
\hline 3. & Yellow bamboo & + & + & + & + & + & + & + \\
\hline 4. & $\begin{array}{l}\text { Umbrella tree } \\
\text { leaves }\end{array}$ & + & + & + & + & - & + & + \\
\hline
\end{tabular}

Remarks : $+=$ contain tested elements

- $=$ does not contain tested elements

isolation of active compounds and testing them on experimental animals.

\section{ACKNKOWLEDGEMENT}

We would like to express our sincere gratitude to the Head of Aek Nauli Forestry Research Institute for facilitating of this research and to Forestry District officers of Karo Regency who had accompanied along the research. Without these supports, the study would not have been possible. We thank to our technicians Salman Zuhri and Andilo E. Siahaan for all the fieldworks and data collection.

\section{REFERENCES}

Alexious, P., \& Demopoulos, V. J. (2010). Medicinal plants used for the treatment of diabetes and its longterm complications. Kerala, India: Transworld Research Network.

Bailey, C. J., \& Day, C. (1998). Traditional plant medicines as treatments for diabetes. Diabetes Care, 12(8), 553-564. Retrieved from http:// care.diabetesjournals.org/content/12/8/553

Batubara, I., Darusman, L. K., Mitsunaga, T., Rahminiwati, M., \& Djauhari, E. (2010). Potency of Indonesian medicinal plants as tyronese inhibitor and antioxidant agent. Journal of Biological Sciences, 10(2), 138 - 144. Retrieved from http://docsdrive.com/pdfs/ ansinet/jbs/2010/138-144.pdf

CITES. (2012). Appendices I, II, and III Convention on International Trade in Endangered Species of Wild Fauna and Flora. Retrieved from http://www. cites.org/eng/app/2012/E-2012-09-25.pdf

Das, A., Gupta, B. K., Nath, B., \& Mustapha, M. S. (2013). An ethnopharmacological study on commonly used traditional plant and herbal treatment in Malaysia for orang asli people.
International Journal of Pharmaceutical Sciences and Research, 4(1), 430-433. Retrieved from http://www.ijpsr.com/V4I1/56 Vol. 4, Issue 1, January 2013, IJPSR, RA 2031, Paper 56.pdf

Dzulkarnaen, B., \& Widowati, L. (1996). Scientific back up of tradisional remedy for obesity. Mirror Medicine, 3, 49-52.

Edoga, H. O., Okwu, D. E., \& Mbaebie, B. O. (2005). Phytochemicals constituents of some Nigerian medicinal plants. African Journal Biotechnology, 4(7), 685-688.

Forestry Planning Agency. (2002). Data and informations of forestry in North Sumatra Province. Jakarta: Forestry Department of Republic Indonesia.

Gerique, A. (2006). An introduction to ethnoecology and ethnobotany theory and methods. Loja, Ecuador: Advanced Scientific Training.

Giri, L. N. (2008). Potential of antioxidative substances on salam leaves: In vivo study in rats hypercholesterolemia and hyperglycemia. (Thesis). Bogor Agriculture Institute, Bogor.

Harborne, J. B. (1987). Methods of extraction and isolation. In Phytochemical methods. London: Chapman and Hall.

Hariana, A. (2007). Medicinal plants and usefulness. Jakarta, Indonesia: Penebar Swadaya.

Harianja, A. H. (2012). Effecting factors that influence of traditional medicines consumption at the conservation forest in Karo Regency, North Sumatra. In Proceeding: Aek. Nauli Forestry Research Institute, Forestry Research and Development Agency, Ministry of Republic Indonesia.

Hasibuan, M. A. S. (2011). Ethnobotany of Angkola Tribal (Case study on Padang Bujur Village around the Nature Reserve Dolok Sibual-buali, South Tapanuli, North Sumatra). Bogor Agriculture University. Retrieved from http:// repository.ipb.ac.id/bitstream/ handle/123456789/49842/E11 mas. pdf? sequence $=1$ 
International Union for Conservation of Nature (IUCN). (2014). The IUCN Red List of Threatened Species. IUCN. Retrieved from http://www.iucnredlist.org/details/33070/0

Karo Regency Statistical Bureau. (2012). Karo in Figures 2012. Kabanjahe, North Sumatra, Indonesia: Statistics Agency of Karo Regency.

Lumbanraja, L. (2008). Testing of ethanol extract on mahogany seed (Swietenia mahagoni Jacq) to decrease blood sugar levels of rats white (Thesis). North Sumatra University, Medan.

Mann, J. (1978). Secondary metabolism. London: Oxford University Press.

Martin, G. J. (1995). Ethnobotany : A "people and plant" conservation manual. London: Chapman and Hall.

Ministry of Forestry of Republic Indonesia. (2010). The integratif research plan: Conservation of flora, fauna and microorganisms. Bogor, Indonesia: Research and Development Center for Conservation and Rehabilitation.

Ministry of Health of Republic Indonesia. (1997). Inventory Indonesian medicinal plants (Volume IV). Jakarta: Ministry of Health of Republic Indonesia.

Ministry of Health of Republic Indonesia. (2012). Diabetes Mellitus, the sixth causes of death in the world: The bid SMART solutions through Posbindu. Retrieved from http://www.depkes.go.id/ index.php? $\mathrm{vw}=2$ \&id $=2383$

Mungmachon, M. R. (2012). Knowledge and local wisdom: community treasure. International Journal of Humanities and Social Science, 2(13), 174-181.

Ngadiwiyana, Ismiyarto, Basid, A. P., \& Purbowatiningrum, R. S. (2011). Potential cinnamaldehid from the insulating oil of cinnamon as an anti diabetic compound. Pharmacy Indonesia Magazine, 22(1), 9-14.

North Sumatra Statistical Bureau. (2012). North Sumatra in Figure 2011. Medan, Indonesia: North Sumatra Statistical Bureau.

Oktavia, J. D. (2011). Optimized extraction of flavonoids from salam leaves (Syzygium polyanthum) and analysis by thin layer chromatography (Thesis). Bogor Agricultural University, Bogor.

Pasaribu, G. T. (2009). Extractive substances of raru wood and the effect on blood sugar levels decline by in vitro (Thesis). Bogor Agricultural University, Bogor.

Rajani, M., \& Kanaki, N. S. (2008). Phytochemical standardization of herbal drugs and poly herbal formulations. In Bioactive Molecules and Medicinal Plants. Gujarat, India: Springer.

Sari, N. I. (2009). Ethnobotany study on herbaceous plants by Karo Community in Leuser Mountain National Park, North Sumatra (Thesis). North Sumatra University, Medan.

Sufriadi, A. (2006). Benefits of cinnamon leaf (Cinnamomum burmanni) efficacy against antioxidant Mabkota Dewa (Phaleria macrocarpa Scheff. Boerl.) during storage. Bogor, Indonesia: Bogor Agricultural University.

Sulistiyani, Falah, S., \& Wahyuni, T. W. (2010). The cellular mechanism of natural antioxidant extracts of jati belanda (Guazuma ulmifolia Lamk.) and salam leaf (Syzygium polyanthum) in the therapy of cardiovascular disease. Bogor, Indonesia: Bogor Agricultural University.

Umar, F. (2008). Optimization of total flavonoids extraction of jati belanda leaves (Guazuma ulmifolia Lamk). Bogor: Bogor Agricultural University.

Waluyo, E. B. (2008). Review: Research ethnobotany in Indonesia and the future perspectives. Biodoversitas, 9(1), 59-63. Retrieved from http://biodiversitas.mipa.uns.ac.id/ D/ D0901/D090114.pdf

Widowati, L., Dzulkarnain, B., \& Sa'roni. (1997). Medical plants for diabetes mellitus (Mirror Medicine No 116). Jakarta: Health Research and Development Agency, Ministry of Health of Republic Indonesia.

Winarti, C., \& Nurdjanah, N. (2005). Opportunities of spices and medicinal plants as a source of functional food. Agricultural Research and Development Journal, 24(2), 47-55. Retrieved from http://pustaka.litbang.deptan.go.id/ publikasi/p3242051.pdf

Windadri, F. I., Rahayu, M., Uji, T., \& Rustiami, H. (2006). Utilisation of medicinal plants by the community of Muna Tribes in District Wakarumba, Southeast Sulawesi. Biodiversitas, 7(4), 333-339. Retrieved from http:// biodiversitas.mipa.uns.ac.id/D/D0704/ D070407.pdf 